\title{
PHYSICAL QUALITY OF SOILS UNDER A CROP-LIVESTOCK-FOREST SYSTEM IN THE CERRADO/AMAZON TRANSITION REGION ${ }^{1}$
}

\author{
Guilherme Musse Moreira², Júlio César Lima Neves², Genelício Crusoé Rocha², Ciro Augusto de Souza \\ Magalhães ${ }^{3}$, Austeclinio Lopes Farias Neto ${ }^{3}$, João Luiz Palma Meneguci ${ }^{3}$ and Raphael B.A. Fernandes ${ }^{2 *}$ \\ ${ }^{1}$ Received on 23.10.2017 accepted for publication on 02.05.2018. \\ ${ }^{2}$ Universidade Federal de Viçosa, Departamento de Solos, Viçosa, MG-Brasil. E-mail: <guilhermemusse@hotmail.com>, \\ <julio_n2003@yahoo.com.br>,<genelicio.rocha@ufv.br> and <raphael@ufv.br>. \\ ${ }^{3}$ Empresa Brasileira de Pesquisa Agropecuária, Embrapa Agrossilvipastoril, Sinop, MT-Brasil. E-mail: <ciro.magalhaes@embrapa.br $>$ \\ , <austeclinio.farias@embrapa.br>and<joao.meneguci@embrapa.br>. \\ *Corresponding author.
}

\begin{abstract}
Integrated crop-livestock-forest (iCLF) systems have gained prominence in the past decades as an alternative of sustainable land use, particularly in regions in which there is pressure against agricultural expansion in protected ecosystems such as the Brazilian Amazon. In this context, the objective of this study is to evaluate the effects of one year of use of the iCLF system in the Cerrado/Amazon transition region to determine its impact on soil quality compared to other traditional land uses in the region (planted forest, crop, forage, and native forest). The results indicated that the iCLF system did not jeopardize the soil physical quality, and only the crop land use affected the soil physical attributes. The land uses with the lowest impact on the physical condition of the soil were the iCLF system and the planted forest.
\end{abstract}

Keywords: Integrated crop-livestock-forest system; Least limiting water range; Agrosilvopastoral system.

\section{QUALIDADE FÍSICA DE SOLO EM SISTEMA DE INTEGRAÇÃO LAVOURA PECUARIA FLORESTA NA REGIÃO DE TRANSIÇÃO ENTRE CERRADO E AMAZÔNIA} RESUMO-Os sistemas de integração lavoura-pecuária-floresta (ILPF) têm ganhado destaque nas últimas
décadas como uma alternativa de uso sustentável das terras, especialmente em regiões onde existe pressão
contra a expansão agropecuária sobre ecossistemas protegidos, como éo caso da Amazônia Brasileira. Neste
contexto, o objetivo deste trabalho foi avaliar os efeitos após um ano da adoção de sistema ILPF em região
de transição Cerrado/Amazonia, buscando verificar suas consequências sobre a qualidade do solo em relação
a outros usos da terra tradicionais na região (floresta plantada, lavoura, pastagem e mata nativa). Os resultados
não indicaram efeitos negativos do sistema ILPF sobre a qualidade fisica do solo, que somente foi impactada
negativamente no tratamento lavoura. Dos usos da terra avaliados, os de menor impacto sobre a qualidade
física do solo foram o sistema de integração lavoura-pecuária-floresta e a floresta plantada.
Palavras-Chave: Integração lavoura pecuária floresta; Intervalo hídrico ótimo; Sistema agrossilvipastoril. 


\section{INTRODUCTION}

Global demand for food is a growing concern. Studies estimate that the world population will reach 9.15 billion people in 2050 , which will require a $60 \%$ increase in food production worldwide (Alexandratos and Bruinsma, 2012). In response to this challenge, in addition to advances in technology and increased productivity, agricultural areas need to be expanded. However, situations in which agricultural expansion puts pressure on areas of environmental relevance or preserved areas are criticized.

The Brazilian Amazon is one of the regions where deforestation is a cause for concern. In this region, the use of integrated production systems to improve the use of cultivated areas and abandoned or degraded areas is a viable and promising alternative. These technological solutions include the integrated croplivestock-forest system (iCLF).

The iCLF system is a technological proposal to ensure sustainable and integrated production and involves components of agricultural, livestock, and forestry production in a same cultivated area using intercrop, sequential, or rotational systems (Balbino et al., 2011). In this integrated system, the soil is one of the main components, and the maintenance of soil quality is essential for the sustainability of the agroecosystem.

One of the challenges of iCLF systems is assessing the yield and sustainability of the system in different biomes. Concerning sustainability, soil quality plays a prominent role because it is a vital parameter in production. Monitoring soil quality is fundamental, especially its physical characteristics, which affect several processes important for the success of the whole system. However, the effects of iCLF systems on soil physical characteristics are conflicting. The effect may be positive, with improvements in soil bulk density (BD) and porosity (Assis et al., 2015), or negative, with a reduction in water infiltration (Bonini et al., 2016). However, the potential effects of this system can be assessed by analyzing this variable in different regions, especially in the Brazilian Amazon, where the expanding agriculture limits the development of native forests and better-preserved biomes. Comparing the performance of the iCLF system with other landmanagement systems is crucial in these regions.

The objective of this study is to evaluate the soil physical characteristics after one year of iCLF system adoption in the Cerrado/Amazonia transition region and compare the performance of this system with other land management systems used in the region.

\section{MATERIALAND METHODS}

\subsection{Study site}

This study was conducted in the Experimental Unit of Embrapa Agrossilvipastoril, located in the city of Sinop, northern Mato Grosso state - Brazil. A central area of the Experimental Unit was demarcated as a

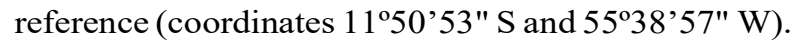
According to the Köppen classification, the local climate is Aw type (tropical with dry winter), with mean annual temperature and rainfall of about $25^{\circ} \mathrm{C}$ and $2,000 \mathrm{~mm}$, respectively. The topography is flat, and the altitude is $364 \mathrm{~m}$. The soil of the Experimental Unit was classified as Red-Yellow Latosol (Embrapa, 2013) with clayey texture (380 $\mathrm{g} \mathrm{kg}^{-1}$ sand, $20 \mathrm{~g} \mathrm{~kg}^{-1}$ silt, and $600 \mathrm{~g} \mathrm{~kg}^{-1}$ clay).

Treatments were implemented in October 2011 and evaluated in November 2012, consisting of the following production systems: iCLF, integrated crop-livestockforest system with Eucalyptus planted in three rows forming a tier intercropped with soybean (first harvest ) and corn (second harvest), followed by pasture during the off-season; EF, Eucalyptus forest; CSC, crop of soybean (summer) and corn from the second harvest (winter) under no-tillage (NT); PF, pasture forage under $\mathrm{NT}$, and NF, native forest used as a reference.

The treatments iCLF and EF included seedlings of the Eucalyptus clone H13 of the hybrid Eucalyptus grandis vs. E. urophylla planted after opening furrows 30 -cm deep and spaced $3 \times 3 \mathrm{~m}$. In the iCLF system, Eucalyptus was planted in tiers, spaced $30 \mathrm{~m}$ apart. Soybean, corn, and forage were cultivated between the tiers. Soybean in the iCLF and CSC systems was planted with a spacing of $45 \mathrm{~cm}$ at a density of 140,000 and 380,000 plants $\mathrm{ha}^{-1}$, respectively, using the BRS Favorita and BRSGO 8560 RR varieties in the first and second year, respectively. Corn (from the second harvest, variety DKB 175) was planted with a spacing of 45 $\mathrm{cm}$ at a density of 55,000 plants ha- ${ }^{-1}$. In the iCLF system, forage was planted together with corn and maintained after corn harvest. The forage used in ICLF and PF was Brachiaria brizantha Hochst. Stapf. Cv. Marandu at a density of $5.5 \mathrm{~kg}$ seeds ha- ${ }^{-1}$ without grazing. Except for the NF, there was traffic of agricultural machinery and implements in the other areas (Table 1).

Revista Árvore. 2018;42(2):e420213 
Table 1 - Traffic of agricultural machinery in different management systems before soil sampling in the Cerrado/Amazon transition region.

Tabela 1 - Trânsito de maquinário realizado nos diferentes sistemas de manejo até o momento da coleta de amostras de solo na região de transição Cerrado/Amazônia.

\begin{tabular}{|c|c|c|c|c|c|c|}
\hline \multirow{2}{*}{ Machinery } & \multirow{2}{*}{$\frac{\text { Weight }}{\mathrm{kg}}$} & \multicolumn{5}{|c|}{ Machinery cross } \\
\hline & & iCLF-T & iCLF-IT & $\mathrm{EF}$ & $\mathrm{CSC}$ & $\mathrm{PF}$ \\
\hline \multicolumn{7}{|l|}{ Tractors } \\
\hline $55 \mathrm{cv}$ & 3705 & & 4 & 2 & 4 & 1 \\
\hline $75 \mathrm{cv}$ & 4125 & 4 & 2 & 4 & 2 & 1 \\
\hline $170 \mathrm{cv}$ & 9350 & & 1 & & & 1 \\
\hline \multicolumn{7}{|l|}{ Implements } \\
\hline Furrow & na & $1(75 \mathrm{cv})$ & & $1(75 \mathrm{cv})$ & & \\
\hline 12-row seeder & 1500 & & $1\left(55 \mathrm{cv}, 2^{\text {nd }}\right.$ year $)$ & & $1\left(55 \mathrm{cv}, 2^{\text {nd }}\right.$ year $)$ & $1(75 \mathrm{cv})$ \\
\hline 15-row seeder & 2500 & & $2\left(75 \mathrm{cv}, 1^{\text {st }}\right.$ year $)$ & & $2\left(75 \mathrm{cv}, 1^{\text {st }}\right.$ year $)$ & \\
\hline Small sprayer* & 920 & & & $2(55 \mathrm{cv})$ & & \\
\hline Large Sprayer* & 1200 & $2(75 \mathrm{cv})$ & $3(55 \mathrm{cv})$ & $2(75 \mathrm{cv})$ & $3(55 \mathrm{cv})$ & $1(55 \mathrm{cv})$ \\
\hline Brush cutter & 250 & $1(75 \mathrm{cv})$ & $1(170 \mathrm{cv})$ & $1(75 \mathrm{cv})$ & & $1(170 \mathrm{cv})$ \\
\hline Harvester** & na & & 3 & & 3 & \\
\hline
\end{tabular}

The study site was previously used for more than 30 years for producing soybean, corn, and cotton using a conventional tillage system. Before the installation of the experiment, except for the NF, harrowing was performed in the total area without subsequent tillage. Four replications of each treatment were organized in a completely randomized block design. The area of each experimental unit was 2 hectares.

The soil samples were collected in November and December of 2012, and treatments were analyzed. At the sampling, there was soybean crop ( $2^{\text {nd }}$ cultivation $)$ between the tiers in the iCLF and CSC systems. Others systems were cultivated with their respective crops.

\subsection{Sample collection}

Disturbed and undisturbed soil samples were collected. The disturbed samples were composite, obtained from four samples used in each experimental unit. These samples were used to evaluate the water clay dispersed (WCD) and the soil organic matter content (SOM). In each experimental unit, four undisturbed samples were collected in the center of the layer with a depth of 0 to $10 \mathrm{~cm}$ using stainless steel rings (height of $5 \mathrm{~cm}$ and diameter of $5 \mathrm{~cm}$ ) for determining soil bulk density (BD) and porosity (TP). In each experimental unit of the $\mathrm{PF}, \mathrm{CSC}$, and $\mathrm{NF}$, additional 30 undisturbed samples were collected in the center of the layers at a depth of $0-10 \mathrm{~cm}$ and $10-20 \mathrm{~cm}$ for determining the soil water retention curve (SWRC), $\mathrm{S}$ index, and least limiting water range (LLWR). In the $\mathrm{iCLF}$ and EF, the effect of the tree component and furrowing performed for planting the seedlings, respectively, on soil water parameters was evaluated by collecting the same number of undisturbed samples at the same depths previously indicated, but in two different positions: in tiers (iCLFT) and between tiers (iCLF-IT) in the iCLF system, and in rows (EF-R) and between rows (EF-IR) in the EF.

All collected samples were analyzed in the Soil Physics Laboratory of the Universidade Federal de Viçosa. The procedures adopted for analyzing $\mathrm{WCD}, \mathrm{BD}$, macroporosity (MAP), microporosity (MIP), TP, and SWRC in the soil followed the recommendations of Embrapa (2011). The LLWR was measured according to Letey (1985), and the S index was determined according to Dexter (2004). The SOM was obtained by analyzing the total organic carbon content (Yeomans and Bremner, 1988).

Aiming for the best-fit, the SWRC was estimated from ten soil water potentials. Soil water retention characteristics were determined using a sandbox-type tension table $(-0.004,-0.006$, and $-0.008 \mathrm{MPa})$ and a pressure plate apparatus $(-0.01,-0.03,-0.05,-0.07$, $-0.1,-0.5$, and $-1.5 \mathrm{MPa})$. The SWRC were adjusted by the model proposed by van Genuchten (1980). Saturation $(\theta s)$ and residual $(\theta s)$ soil water contents were treated as independent variables and were assumed 
to be equivalent to total porosity and equilibrium moisture, with a potential of $-1.5 \mathrm{MPa}$. This model was adjusted using the software SWRC ${ }^{\circledR}$ version 3.0 (Dourado Neto et al., 2000). The $\mathrm{S}$ index was calculated using the adjustment parameters of the van Genuchten model (Dexter, 2004).

For measuring the LLWR, each group of three undisturbed samples was subjected to one of the ten soil water potentials used to construct the soil water retention curve. After equilibration at the tension table or porous plate, the samples were weighed and subjected to analysis of soil penetration resistance (PR) using a Marconi electronic penetrometer model MA-933 according to Tormena et al. (1998). The analyses were conducted in the center of each sample along the ring height, discarding the values obtained in the first centimeter of the upper and lower extremities. After determining the $\theta_{\mathrm{PR}}$, the samples were dried in an oven at $105^{\circ} \mathrm{C}$ for 48 hours, and moisture $(\theta)$ and BD were measured. The $\theta_{\mathrm{PR}}$ values were adjusted relative to BD and $\theta$ using the non-linear regression model proposed by Busscher (1990) according to equation $P R=a . \theta^{b} \cdot S B D^{o}$. The $\theta$ values were adjusted relative to $\mathrm{BD}$ and soil water potential $(\psi)$ using the non-linear regression model proposed by Tormena et al. (1998) according to equation $\theta=E X P$ $(d+e . S B D) . X^{f}$.The adjustment parameters $(a, b, c, d$, $e$, and $f$ ) of these equations were obtained using Statistica ${ }^{\circledR}$ software.

The LLWR was measured using an algorithm developed in EXCEL $\AA$ (Leão and Silva, 2004), which allowed generating a graph from the equations $\theta_{F C}=E X P(d+e . S B D) .0 .01^{f}$, $\theta_{P W P}=E X P(d+e . S B D) .1 .5^{f}, \theta_{A P}=[1-(S B D / P D)]-0.1$ e $\theta_{P R}=\left(2 / a \cdot S B D^{c}\right)^{(1 / b)}$, which correlate $\mathrm{BD}$ with soil moisture $(\theta)$ at field capacity $\left(\theta_{F C}\right)$, equivalent to a potential of $-0.01 \mathrm{MPa}$; moisture $(\theta)$ at the permanent wilting point $\left(\theta_{P W P}\right)$, equivalent to a potential of -1.5 $\mathrm{MPa}$; moisture $(\theta)$ when aeration porosity $\left(\theta_{A P}\right)$ is $\leq 0.1$ $\mathrm{m}^{3} \mathrm{~m}^{-3}$; and moisture $(\theta)$ when $\mathrm{è}_{P R}$ reached $2.0 \mathrm{MPa}$. The limits indicated previously were used in the algorithm considering the values of $\theta_{F C}, \theta_{P W P}, \theta_{A P}$, and $\theta_{P R}$ proposed by Haise et al. (1955), Richards and Weaver (1943), Grable and Siemer (1968), and Taylor et al. (1966), respectively.

\subsection{Statistical analysis}

For data analysis, the results were evaluated using the Shapiro-Wilk test and Levene test to confirm the presence of data normality and variance homogeneity. When necessary, the data were transformed to perform

Revista Árvore. 2018;42(2):e420213 analysis of variance (ANOVA). The Tukey test was used to compare the treatments at a level of significance of $5 \%$.

\section{RESULTS}

\subsection{Soil Physical analysis}

The different production systems did not affect the levels of clay dispersed in water but decreased soil organic matter relative to the NF (Table 2). The BD was $16 \%$ higher in the CSC compared with the NF. The BD values in the iCLF, EF, and PF were similar and were not significantly different from those of the CSC and NF.

In most cases, total soil porosity was not affected by the evaluated systems compared with the NF. Total soil porosity was significantly higher in the iCLF compared with the CSC, although there were no significant differences in macro- (MAP) and microporosity (MIP) between these two areas. Macroporosity was significantly different between the CSC and NF. The NF soil presented a macroporous volume $51.8 \%$ higher than the CSC soil, and this difference corresponds to a macropore volume of $0.14 \mathrm{~m}^{3}$ between these two systems (Table 2).

Soil microporosity did not vary significantly between the systems but was changed in the iCLF compared with the NF. Although MIP was not decreased and total porosity TP was not increased, the iCLF system presented $23.8 \%$ more micropores than the NF.

The removal of native vegetation changed the distribution of MAP and MIP in the evaluated soils. The mean distribution was $46 \%$ of the MAP and $54 \%$ of the MIP in the NF and $30 \%$ of the MAP and $70 \%$ of the MIP in the cultivated areas.

\subsection{Water retention curve and $S$ index}

The adjustment using the van Genuchten equation for soil water retention curve (SWRC) data generated equations considered adequate $\left(\mathrm{R}^{2} \geq 0.96\right)$ for all analyzed treatments and depths (Table 3 ). The comparison between the management systems indicated that there were significant differences between the coefficients related to saturation moisture $(\theta \mathrm{s})$, residual moisture $(\theta \mathrm{r})$, and available water content ( $($ awc). In the superficial layer $(0-10 \mathrm{~cm})$, the soil management used in the iCLF-IT 
Table 2 - Physical attributes of a Yellow-Red Latosol of Sinop (Mato Grosso, Brazil) subjected to different land management systems in the Cerrado/Amazon transition region .

Tabela 2 - Atributos físicos de um Latossolo Vermelho Amarelo de Sinop (MT) submetido a diferentes usos da terra na região de transição entre Cerrado e Amazônia.

\begin{tabular}{|c|c|c|c|c|c|c|}
\hline Treatments & $\begin{array}{c}\text { WCD } \\
\%\end{array}$ & $\begin{array}{c}\mathrm{BD} \\
\mathrm{g} \mathrm{cm}^{-3}\end{array}$ & T P & $\begin{array}{c}\text { MAP } \\
-\mathrm{m}^{3} \mathrm{~m}^{-3}\end{array}$ & MIP & $\begin{array}{c}\text { SOM } \\
\text { dag kg-1 }\end{array}$ \\
\hline iCLF & 8.70 & $1.04 \mathrm{ab}$ & $0.61 \mathrm{a}$ & $0.19 \mathrm{ab}$ & $0.42 \mathrm{a}$ & $4.77 \mathrm{~b}$ \\
\hline $\mathrm{EF}$ & 9.40 & $1.14 \mathrm{ab}$ & $0.55 \mathrm{ab}$ & $0.16 \mathrm{ab}$ & $0.39 \mathrm{ab}$ & $4.59 \mathrm{~b}$ \\
\hline $\mathrm{CSC}$ & 10.30 & $1.18 \mathrm{a}$ & $0.52 \mathrm{~b}$ & $0.13 \mathrm{~b}$ & $0.39 \mathrm{ab}$ & $4.80 \mathrm{~b}$ \\
\hline $\mathrm{PF}$ & 9.30 & $1.06 \mathrm{ab}$ & $0.57 \mathrm{ab}$ & $0.19 \mathrm{ab}$ & $0.38 \mathrm{ab}$ & $4.88 \mathrm{~b}$ \\
\hline NF & 10.40 & $0.99 \mathrm{~b}$ & $0.59 \mathrm{ab}$ & $0.27 \mathrm{a}$ & $0.32 \mathrm{~b}$ & $7.99 \mathrm{a}$ \\
\hline $\mathrm{CV} \%$ & 17.40 & 8.96 & 7.55 & 34.12 & 12.49 & 26.53 \\
\hline
\end{tabular}

WCD, clay dispersed in water; BD, soil density; TP, total porosity; MAP, macroporosity; MIP, microporosity; SOM, soil organic matter; $\mathrm{CV}=$ coefficient of variation. The means followed by the same letter in the column did not differ using Tukey's test ( $\mathrm{p}<0.05$ ).

and CSC reduced the $\theta$ s values compared with the NF. In addition, the $\theta$ awc in the PF was $38.3 \%$ higher than that in the NF.

In the subsurface layer $(10-20 \mathrm{~cm})$, the management systems affected the saturation moisture, with a decrease in $\theta$ s values by $7.2 \%, 7.4 \%, 8.4 \%$, and $16.5 \%$ in the PF, iCLF-IT, EF-IR, and CSC, respectively, compared with the NF. However, this reduction was not observed in the areas of lower traffic of agricultural machinery, as in the tiers in the iCLF and rows in the EF. In turn, the available water capacity was not affected by the management systems in the subsurface layer.
The S index proposed by Dexter (2004) is used to evaluate soil quality. In theory, the limit used to separate soils of good and poor structural quality is an $\mathrm{S}$ value of 0.035 , and values lower than 0.020 indicate poor quality. The $S$ index values were higher than 0.035 in all management systems and analyzed depths (Table 3 ).

\subsection{Least Limiting Water Range (LLWR)}

In all management systems and depths, the upper limit of the LLWR was defined by field capacity, indicating that variations in $\mathrm{BD}$ did not affect aeration porosity at levels that could limit root development (Figure 1).

Table 3 - Coefficients of the Van Genuchten equation and S index of a Yellow-Red Latosol of Sinop (Mato Grosso, Brazil) subjected to different land management systems in the Cerrado/Amazon transition region .

Tabela 3 - Coeficientes da equação de Van Genuchten e indice S de um Latossolo Vermelho Amarelo de Sinop (MT), submetido a diferentes usos da terra na região de transição entre Cerrado e Amazônia.

\begin{tabular}{|c|c|c|c|c|c|c|c|c|}
\hline \multirow{3}{*}{ Systems } & $\alpha^{(1)}$ & $\mathrm{n}^{(1)}$ & $\mathrm{m}^{(1)}$ & $\theta \mathrm{s}$ & $\theta \mathrm{r}$ & Өawc & \multirow[t]{2}{*}{$\mathrm{R}^{2}$} & \multirow[t]{2}{*}{$\mathrm{S}$} \\
\hline & $(1 / \mathrm{kPa})$ & \multirow{2}{*}{\multicolumn{7}{|c|}{$\frac{-\mathrm{m}^{3} \mathrm{~m}^{-3}}{0-10 \mathrm{~cm} \mathrm{layer}^{-}}$}} \\
\hline & & & & & & & & \\
\hline iCLF-IT & 1.056 & 4.490 & 0.128 & $0.546 b c$ & $0.242 \mathrm{a}$ & $0.053 \mathrm{c}$ & 0.977 & 0.140 \\
\hline iCLF-T & 0.785 & 4.136 & 0.165 & $0.602 \mathrm{a}$ & $0.200 \mathrm{bc}$ & $0.099 \mathrm{bc}$ & 0.996 & 0.173 \\
\hline EF-IR & 0.341 & 1.001 & 1.046 & $0.611 \mathrm{a}$ & $0.196 b c$ & $0.067 \mathrm{bc}$ & 0.993 & 0.103 \\
\hline EF-R & 0.240 & 0.679 & 1.140 & $0.607 a$ & $0.192 \mathrm{c}$ & $0.117 \mathrm{ab}$ & 0.991 & 0.063 \\
\hline CSC & 0.586 & 5.363 & 0.133 & $0.520 \mathrm{c}$ & $0.231 \mathrm{ab}$ & $0.077 \mathrm{bc}$ & 0.989 & 0.162 \\
\hline PF & 0.289 & 1.074 & 0.481 & $0.573 \mathrm{ab}$ & $0.212 \mathrm{abc}$ & $0.154 \mathrm{a}$ & 0.979 & 0.063 \\
\hline \multirow[t]{2}{*}{$\mathrm{NF}$} & 3.592 & 1.940 & 0.254 & $0.602 \mathrm{a}$ & $0.193 \mathrm{c}$ & $0.095 \mathrm{bc}$ & 0.991 & 0.039 \\
\hline & & \multicolumn{7}{|c|}{$10-20 \mathrm{~cm}$ layer } \\
\hline iCLF-IT & 1.199 & 2.542 & 0.235 & $0.539 b c$ & $0.265 \mathrm{ab}$ & 0.087 & 0.992 & 0.112 \\
\hline iCLF-T & 0.322 & 0.676 & 1.151 & $0.567 \mathrm{ab}$ & $0.247 \mathrm{abc}$ & 0.058 & 0.960 & 0.055 \\
\hline EF-IR & 1.163 & 3.161 & 0.155 & $0.533 \mathrm{c}$ & $0.222 \mathrm{abc}$ & 0.062 & 0.977 & 0.098 \\
\hline EF-R & 0.057 & 0.633 & 2.031 & $0.582 \mathrm{a}$ & $0.195 \mathrm{c}$ & 0.090 & 0.970 & 0.059 \\
\hline $\mathrm{CSC}$ & 0.005 & 0.534 & 5.856 & $0.486 \mathrm{~d}$ & $0.256 \mathrm{abc}$ & 0.079 & 0.967 & 0.047 \\
\hline $\mathrm{PF}$ & 0.276 & 0.908 & 1.039 & $0.540 \mathrm{bc}$ & $0.274 \mathrm{a}$ & 0.045 & 0.980 & 0.055 \\
\hline NF & 11.174 & 2.491 & 0.119 & $0.582 \mathrm{a}$ & $0.200 \mathrm{bc}$ & 0.098 & 0.993 & 0.078 \\
\hline
\end{tabular}

$\theta \mathrm{s}=$ saturated soil moisture; $\theta \mathrm{r}=$ soil moisture at the permanent wilting point $(-1.5 \mathrm{MPa}) ; \theta$ awc $=$ available water content $\left(\theta_{\mathrm{FC}}-\theta_{\mathrm{PWP}}\right)$. ${ }^{(1)}$ Empirical parameters of the Van Genuchten equation (significant at $\mathrm{p}<0.05$ ). S, S index. Values followed by the same letters in the column did not differ using Tukey's test $(\mathrm{p}<0.05)$. 
In the surface layer $(0-10 \mathrm{~cm})$ (Figure $1 \mathrm{~A})$, the moisture associated with $\theta_{\mathrm{PR}}$ delimited the lower limit of the OWC in the iCLF-IT, EF rows, and CSC, indicating that the land management systems used in these areas may have changed the physical condition of the soil, especially in the CSC, where the $\theta_{\mathrm{PR}}$ almost canceled the LLWR. In contrast, in the NF, the $\theta_{\mathrm{PR}}$ did not limit root development in the soil densities evaluated.

In the subsurface layer (10-20 cm, Figure 1B), the lower and upper limits of the LLWR were defined as that of the superficial layer. The most common condition was that $\theta_{\mathrm{PR}}$ defined the lower limit whereas $\theta_{\mathrm{FC}}$ defined the upper limit of the LLWR in the evaluated systems.

\section{DISCUSSION}

Even after only one agricultural year has been completed and another one had started, the system used in the CSC affected the physical characteristics of the soil. In areas under NT, the traffic of agricultural machinery strongly affected BD (Silveira, 2008). However, the influence of tree roots and forage in the other cultivated areas cannot be ruled out (Calonego and Rosolem, 2011).

The effects of integrated agricultural systems have often been compared to preserved areas, and the $\mathrm{BD}$ is sensitive to changes in the soil physical characteristics because this attribute is considered a good indicator of soil quality. BD is directly associated with other important soil attributes, including penetration resistance, macroporosity, and water infiltration (Cunha et al., 2011; Panachuki et al., 2011; Fernandes et al., 2016). Although the iCLF, EF, and PF used mechanized systems, BD did not change in these areas. A similar result was observed by Araújo et al. (2010), wherein even after three years of land management, there was little variation in BD in Yellow Latosol between different integrated production systems and a native Cerrado area, although there were small variations in soil texture.

Although BD was increased in the CSC, this increase may not be a problem in the long-term because the iCLF system and others conservation systems in the CSC such as NT can mitigate the effects of soil compaction because of lower soil movement, formation of biopores and input of organic matter (Strudley et al., 2008; He et al., 2011).
The total porosity (TP) is a commonly assessed physical characteristic, and differences between crops and integrated production systems are common (Marchão et al., 2007a; Piva et al., 2009).

The reduction of the MAP in the CSC compared with the NF may be directly correlated with higher BD in the CSC. Similarly, Schiavo and Colodro (2012) observed improvements of the MAP in a Yellow Latosol after eight years of conversion from native Cerrado to agricultural use.

The combination of cultures in the iCLF system with different root systems may have favored the formation of small biopores, contributing to the higher volume of MIP in this system (Table 2). Soil microporosity in integrated systems was higher than that of pasture areas (Assis et al., 2015). In contrast, Silva et al. (2011) observed that the volume of MIP in crop-livestockforest and livestock-forest systems was smaller than that of native forests, which disagrees with our results.

The lower èawc (Table 3 ) in the iCLF-IT, EF-IR, and CSC systems may be associated with the traffic intensity of agricultural machinery (Table 1), although there was no association of this variable with the decrease in total porosity and macroporosity, except in the CSC (Table 2). This result indicates that $\theta$ awc may be responsive to changes in soil quality promoted by land management. In turn, the increase in $\theta$ awc in the PF may be related to the effect of the forage root system on the soil structure.

The variations in $\theta \mathrm{s}, \theta \mathrm{r}$, and èawc may be more strongly correlated with changes in soil structure and density (Beutler et al., 2002) than in the organic matter content because $\theta$ s and $\theta$ awc in NF soils were not increased although the organic matter content was increased (Table 2). In contrast, considering that the total organic matter content represents the total organic compounds in the soil and does not allows to define about the quality of these compounds, the contribution of organic matter for the structure and availability of water in soils cannot be neglected.

The parameters $\theta, \mathrm{n}$, and $\mathrm{m}$ of the van Genuchten equation (Table 3 ) are commonly used as indicators of soil physical quality. However, the physical characteristics that may be useful to monitor soil quality do not depend on these parameters. This gap indicates doubts on the feasibility of using these parameters

Revista Árvore. 2018;42(2):e420213 
$0-10 \mathrm{~cm}$ layer
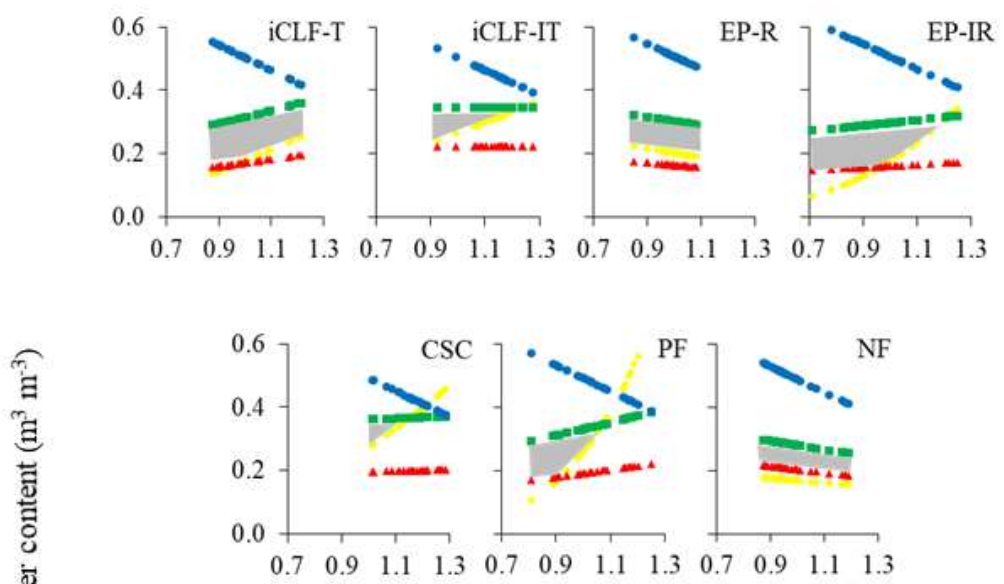

$10-20 \mathrm{~cm}$ layer
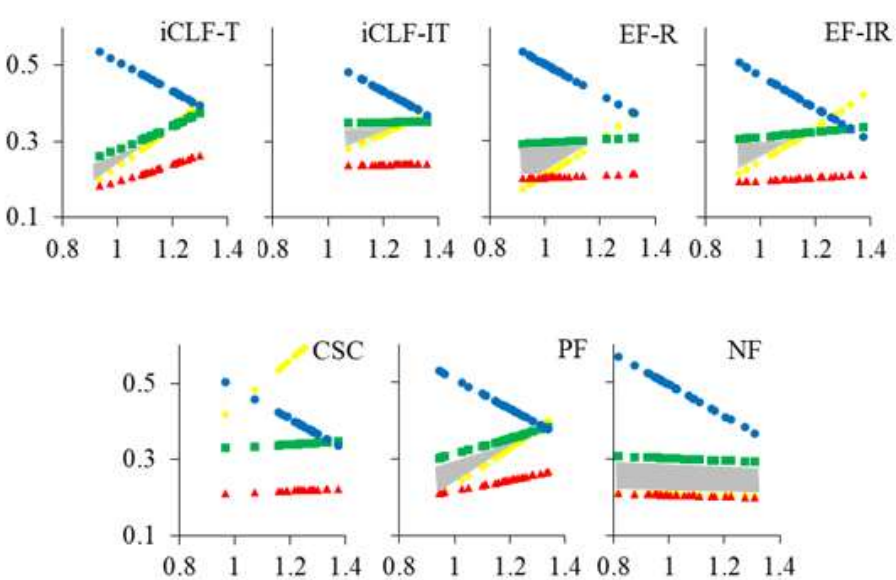

Soil bulk density $\left(\mathrm{g} \mathrm{cm}^{-3}\right)$

- $\theta_{\mathrm{AP}}=\theta_{\mathrm{FC}} \quad \theta_{\mathrm{PR}} \wedge \theta_{\mathrm{PWP}}$

Figure 1 - Least limiting water range (LLWR) of a Latosol subjected to different land management systems in the Cerrado/ Amazon transition region in Sinop (Mato Grosso, Brazil) in the $0-10 \mathrm{~cm}$ and $10-20 \mathrm{~cm}$ soil layers. The LLWR is obtained from the moisture values associated with aeration porosity $\left(\theta_{\mathrm{AP}}\right)$, field capacity $\left(\theta_{\mathrm{FC}}\right)$, permanent wilting point $\left(\theta_{\mathrm{PWP}}\right)$, and soil penetration resistance $\left(\theta_{\mathrm{PR}}\right)$ of $2 \mathrm{MPa}$. Treatments: crop-livestock-forest system in tiers (iCLF-T), crop-livestock-forest between tiers (iCLF-IT); Eucalyptus forest in rows (EF-R) and between rows (EFIR); crops of soybean and corn (CSC); pasture forage (PF), and Native forest (NF).

Figura 1 - Intervalo hídrico ótimo (IHO) de um Latossolo submetidos a diferentes usos da terra na região de transição entre Cerrado e Amazônia em Sinop - MT, nas camadas de 0-10 cm (A) e de 10-20 cm (B) de profundidade. IHO obtido a partir dos valores de umidade associados à: porosidade de aeração $\left(\theta_{A P}\right)$, capacidade de campo $\left(\theta_{F C}\right)$, ponto de murcha permanente $\left(\theta_{P W P}\right)$ e resistência do solo à penetração $\left(\theta_{P R}\right)$ de 2 MPa. Tratamentos:integração lavoura pecuária floresta no renque (iCLF-T) e entre renques ( $i C L F-I T)$ floresta plantada na linha $(E F-R)$ e entre linhas (EF-IR); lavoura (CSC); pastagem (PF) e fragmento florestal nativo (NF). 
other than the water retention curve to analyze soil quality because in practice the interpretation of these parameters is limited.

The $\mathrm{S}$ index is generic but provides important information about the physical condition of the soil. In this study, the $\mathrm{S}$ index of all systems was higher than 0.035 , indicating the presence of good soil structure. Similar results were found by Marchão et al. (2007b) in soils under integrated production, monoculture, and NF systems. However, in the study by Marchão et al. (2007b) and Silva et al. (2008), the S index in the NF was higher than that of the other systems, which contrasts with our results, particularly in the surface layer, where the NF had the lowest $\mathrm{S}$ index. A possible explanation for the low $\mathrm{S}$ index in the NF soil is the large volume of macropores in the superficial layer, which caused rapid loss of water in the higher potentials, directly affecting the parameters of the van Genuchten equation and, consequently, the point of inflection of the retention curve used in estimating the $\mathrm{S}$ index. This higher MAP in the surface of NF should be associated with good soil water infiltration, indicating that is a necessary caution to interpret the van Genuchten parameters and $\mathrm{S}$ index.

The penetration resistance was a stronger limiting factor in the $0-10 \mathrm{~cm}$ layer. In the iCLF-IT, EF-IR, and $\mathrm{CSC}$, the $\theta_{\mathrm{PR}}$ limited plant development before soil moisture restriction. In studies with crops under NT and integrated crops, Petean et al. (2010) and Calonego et al. (2011) found that $\theta_{\mathrm{PR}}$ corresponded to the lower limit of the LLWR. In the iCLF-IT and EF-IR, the moisture at the permanent wilting point $\left(\theta_{\text {PWP }}\right)$ defined the lower limit of the LLWR until a density of approximately $1.0 \mathrm{~g}$ $\mathrm{cm}^{-3}$, when the $\theta_{\mathrm{PR}}$ was more limiting. A similar result was observed by Petean et al. (2010) in soils under the integrated crop-livestock systems at a density of $1.12 \mathrm{~g} \mathrm{~cm}^{-3}$.

In this study, $2 \mathrm{MPa}$ was considered the critical value for $\theta_{\mathrm{PR}}$ (Taylor et al., 1996). However, this value is not a consensus. Some authors consider that this value can be increased in NT systems because of the higher temporal availability of water associated with the soil cover, especially in the presence of a continuous, active, and stable network of biopores, which serve as alternative routes to the root system of crops (Petean et al., 2010).

\footnotetext{
Revista Árvore. 2018;42(2):e420213
}

The NF was the only area where $\theta_{P R}$ was not a limiting factor. Similar results were observed by Araújo et al. (2004) and were attributed to the preserved structure of this environment. The better structural quality is more evident in the subsurface layer $(10-20 \mathrm{~cm})$, where $\theta_{\mathrm{PR}}$ values were lower than 2.0 MPa.

It is of note that although there were limitations imposed by $\theta_{\mathrm{PR}}$ in the evaluated systems, local environmental conditions such as water regime and the adopted management system (NT) may attenuate this limitation.

Our results indicated that the physical characteristics of the soil were changed in the evaluated management systems. Considering that the whole study area was managed using a similar approach and using crops, the introduction of integrated or grazing systems changed the physical characteristics of the soil in the short term. This effect may be related to changes in edaphic conditions imposed by the presence of different root systems provided by trees and forages. In turn, in the $\mathrm{CSC}$, the maintenance of annual crops did not improve the soil structure, even under NT.

\section{CONCLUSION}

The integrated crop-livestock-forest system has the potential to improve soil physical quality in the short term. Planted forests and pasture may provide the same potential but without the advantages of products provided by integrated systems. In contrast, soil quality is not improved in annual crops using a single-crop system.

\section{ACKNOWLEDGMENTS}

We thank to the National Council for Scientific and Technological Development (CNPq, Brazil), the Coordenação de Aperfeiçoamento de Pessoal de Nível Superior (CAPES, Brazil, Finance Code 001) and the Brazilian Agricultural Research Corporation (EMBRAPA) for funding the study.

\section{REFERENCES}

Alexandratos N, Bruinsma J. World agriculture towards 2030/2050: the 2012 Revision. Roma: FAO Agricultural Development Economics Division; 2012.

Araújo FS, Salviano AAC, Leite LFC, Souza ZM, Sousa ACM. Physical quality of a Yellow Latossol under integrated crop-livestock system. Revista 
Brasileira de Ciência do Solo. 2010;34(3):717-23.

Araújo MA, Tormena CA, Silva A. Propriedades físicas de um Latossolo Vermelho distrófico cultivado e sob mata nativa. Revista Brasileira de Ciência do Solo. 2004;28(2):337-45.

Assis PCR, Stone LF, Medeiros JC, Madari BE, Oliveira JM, Wruck FJ. Atributos físicos do solo em sistemas de integração lavoura-pecuáriafloresta. Revista Brasileira de Engenharia Agrícola e Ambiental. 2015;19(4):309-16.

Balbino LC, Barcellos AO, Stone LF. Marco referencial: integração lavoura-pecuária-floresta. Brasília, DF: Embrapa; 2011.

Beutler AN, Centurion JF, Souza ZM, Andrioli I, Roque CG. Retenção de água em dois tipos de Latossolos sob diferentes usos. Revista Brasileira de Ciência do Solo. 1002;26(3):829-34.

Bonini CSB, Lupatini GC, Andrighetto C, Mateus GP, Heinrichs R, Aranha AS, Santana EAR, Meirelles GC. Produção de forragem e atributos químicos e físicos do solo em sistemas integrados de produção agropecuária. Pesquisa Agropecúaria Brasileira. 2016;51(9):1695-8.

Busscher WJ. Adjustment of flat-tipped penetrometer resistance data to a common water content. Transactions of the ASAE. 1990;33(2):519-24.

Calonego JC, Borghi E, Crusciol CAC. Intervalo hídrico ótimo e compactação do solo com cultivo consorciado de milho e braquiária. Revista Brasileira de Ciência do Solo. 2011;35(6):2183-90.

Calonego JC, Rosolem CA. Least limiting water range in soil under crop rotations and chiseling. Revista Brasileira de Ciência do Solo. 2011;35(3):759-71.

Cunha EQ, Stone LF, Ferreira EPB, Didonet AD, Moreira JAAÇ, Leandro WM. Sistemas de preparo do solo e culturas de cobertura na produção orgânica de feijão e milho: II - atributos biológicos do solo. Revista Brasileira de Ciência do Solo. 2011;35(2):603-11.

Dexter AR. Soil physical quality. Part I. Theory, effects of soil texture, density, and organic matter, and effects on root growth. Geoderma. 2004;120(34):201-14.

Dourado Neto D, Nielsen DR, Hopmans JW, Reichardt K, Bacchi OOS. Software to model soil water retention curves (SWRC, version 2.00). Scientia Agricola. 2000;57(1):191-2.

Empresa Brasileira de Pesquisa Agropecuária Embrapa. Manual de métodos de análise de solo. Rio de Janeiro: Embrapa Solos; 2011.

Empresa Brasileira de Pesquisa Agropecuária Embrapa. Sistema brasileiro de classificação de solos. $3^{\text {a }}$. ed. Brasília, DF: 2013.

Fernandes KL, Ribon AA, Tavares Filho J, Custódio GD, Barros LR. Influence of time management in modeling of curve resistance to the penetration of a Latosol under different uses and management of pastures and native woodland. Revista Árvore. 2016;40(3):519-27.

Grable AR, Siemer EG. Effects of bulk density, aggregate size, and soil water suction on oxygen diffusion, redox potential and elongation of corn roots. Soil Science Society of America Journal. 1968;32(2):180-6.

Haise HR, Haas HJ, Jensen LR. Soil moisture studies of some Great Plains soils. II. Field capacity as related to $1 / 3$-atmosphere percentage, and minimum point as related to $15-$ and $26-$ atmosphere percentage. Science Society of America Journal. 1955;19(1):20-5.

He J, Li H, Rasaily RG, Wang Q, Cai G, Su Y, et al. Soil properties and crop yields after 11 years of no tillage farming in wheat-maize cropping system in North China Plain. Soil Tillage Research. 2011;113(1):48-54.

Leão TP, Silva AP. A simplified Excel® algorithm for estimating the least limiting water range of soils. Scientia Agricola. 2004;61(6):649-54.

Letey J. Relationship between soil physical properties and crop production. In: Stewart BA, organizer. Advance in Soil Science. New York: Springer; 1985. p.277-94.

Marchão RL, Balbino LC, Silva EM, Santos Junior JDG, Sá MAC, Vilela L, et al. Qualidade física de 
um Latossolo Vermelho sob sistemas de integração lavoura-pecuária no Cerrado. Pesquisa Agropecúaria Brasileira. 2007a;42(6):873-82.

Marchão RL, Santos Junior JDG, Silva EM, Sá MAC, Balbino LC, Vilela L, et al. Parâmetro "S" e intervalo hídrico ótimo em Latossolo Vermelho sob sistemas de integração lavoura-pecuária no Cerrado [CD-ROM]. In: Anais do $31^{\circ}$ Congresso Brasileiro de Ciência do Solo. Gramado: 2007. Gramado: Sociedade Brasileira de Ciência do Solo; $2007 b$.

Panachuki E, Bertol I, Sobrinho TA, Oliveira PTS, Rodrigues DBB. Perdas de solo e de água e infiltração de água em Latossolo Vermelho sob sistemas de manejo. Revista Brasileira Ciência Solo. 2011;35(5):1777-86.

Petean LP, Tormena CA, Alves SJ. Intervalo hídrico ótimo de um Latossolo Vermelho distroférrico sob plantio direto em sistema de integração lavoura-pecuária. Revista Brasileira Ciência do Solo. 2010;34(5):1515-26.

Piva JT, Hubner LC, Dieckow J, Favaretto N, Pauletti V. Atributos físicos de um Latossolo em sistemas de preparo e integração lavourapecuária. In: Anais da 1a Reunião Paranaense de Ciência do Solo, 2009. Pato Branco: Reunião Paranaense de Ciência do Solo; 2009. p.23-3.

Richards LA, Weaver LR. Fifteen-atmosphere percentage as related to the permanent wilting percentage. Soil Science. 1943;56(5):331-9.

Schiavo JA, Colodro G. Agregação e resistência à penetração de um Latossolo Vermelho sob sistema de integração lavoura-pecuária. Bragantia. 2012;71(3):406-12.

Silva FDF, Freddi OS, Centurion JF, Aratani RG,
Andrioli FF, Andrioli I. Propriedades físicas de um Latossolo Vermelho cultivado no sistema plantio direto. Irriga. 2008;13(2):191-204.

Silva GL, Lima HV, Campanha MM, Gilkes RJ, Oliveira TS. Soil physical quality of Luvisols under agroforestry, natural vegetation and conventional crop management systems in the Brazilian semi-arid region. Geoderma. 2011;167/ 168:61-70.

Silveira PM, Sotne LF, Alves Júnior J, Silva JG. Efeitos do manejo do solo sob plantio direto e de culturas na densidade e porosidade de um Latossolo. Bioscience Journal. 2008;24(3):53-9.

Strudley MW, Green TR, Ascough JC. Tillage effects on soil hydraulic properties in space and time: State of the science. Soil Tillage Research. 2008;99(1): 4-48.

Taylor HM, Roberson GM, Parker Jr JJ. Soil strength-root penetration relations to medium to coarse-textured soil materials. Soil Science.1966;102(1):18-22.

Tormena CAS, Silva AP, Libardi PL. Caracterização do intervalo hídrico ótimo de um Latossolo Roxo sob plantio direto. Revista Brasileira de Ciência do Solo. 1998;22(4):573-81.

van Genuchten MT. A closed-form equation for predicting the hydraulic conductivity of unsaturated soils. Soil Science Society of America Journal. 1980;44(5):892-8.

Yeomans JC, Bremner JM. A rapid and precise method for routine determination of carbon in soil. Communications in Soil Science and Plant Analysis. 1988;19(13):1467-76. 